\title{
FALL MIGRATION OF BALD EAGLES PRODUCED IN NORTHERN SASKATCHEWAN
}

ALAN R. HARMATA and JOHN E. TOEPFER, Department of Biology, Fish and Wildlife Program, Montana State University, Bozeman, Montana, 59715 and JON M. GERRARD, R.R. 1, Box 113, Headingly, Manitoba. ROH $0 J 0$.

Between January and March 1980 and 1981, six adult Bald Eagles radio-tagged on their wintering grounds in the San Luis Valley of south-central Colorado, were tracked to summering grounds in northcentral and northeastern Saskatchewan and western Manitoba. ${ }^{7}$ Intensive investigations of summering Bald Eagles in this part of western Canada had been in progress for many years and the information generated from both projects was complimentary. ${ }^{6} 1$ $\begin{array}{llll}5 & 2 & 10 & 12\end{array}$

The situation presented a unique opportunity to document the complete annual cycle of a relatively discrete population through a cooperative effort including researchers from both projects. In July 1982, a breeding pair was captured and radiotagged with tail-mounted transmitters on Besnard Lake $\left(55^{\circ} 20^{\prime} \mathrm{N}, 106^{\circ} 00^{\prime} \mathrm{W}\right)$. Subsequent tracking produced much unique data concerning home range size and use, territoriality, activity, and intra-range movements of adults with young. ${ }^{3}$ However, sequence and timing of tail feather molt undocumented prior to this study, did not permit retention of transmitters for tracking eagles on fall migration, and additional pairs were not captured at that time. An additional breeding adult was captured on 1 September but its molt had still not progressed sufficiently to insure retention of the transmitter for the duration of migration. However, a transmitter was mounted on two of the new tail feathers and this bird was later followed for 5 days of migration. ${ }^{11}$ Since tail-mount packages are preferred over any other method of attaching transmitters on adult eagles, it was evident that capture and marking of adults after 1 October would be required. Instrumented adults indeed dropped the transmitters between 9 September and 6 October. Logistical and financial constraints dictated cessation of work for the 1982 season.

In 1983, adult and nestling eagles from three family groups were to be fitted with radio transmitters on Besnard Lake. The primary objectives of the study were to:

(1) determine if family groups of Bald Eagles remain together on fall migration and document behavior and interactions among and between family groups

(2) identify stopover areas used on fall migration

(3) identify the routes and mechanics of fall migration

(4) determine the wintering grounds of eagles from a known breeding/natal area.

\section{Methods}

Nestling Bald Eagles were fitted with 80 90-g solar powered transmitters attached by backpack harnesses. Transmitters were AVM 2B5 2-stage with 10 solar panels. Solar transmitters have a theoretical unlimited life but realistically may function up to 5 years. The backpack attachment was designed to be shed no longer than 5 years from installation.

Nestlings were radio-tagged at 7 to 9 weeks of age. Each nestling was taken from the nest, banded, measured, radio-tagged and returned to the nest. 


\section{ERRATUM: FALL MIGRATION OF BALD EAGLES PRODUCED IN NORTHERN SASKATCHEWAN.}

ALAN R. HARMATA and JOHN E. TOEPFER, Department of Biology, Fish and Wildlife Program, Montana State University, Bozeman, Montana, 59715 and JON M. GERRARD, R.R. 1, Box 113, Headingly, Manitoba. ROH 0J0 Blue Jay 43(4):232-237.

Please remove this page and insert between pages 232 and 233 of the December 1985 issue of Blue Jay.

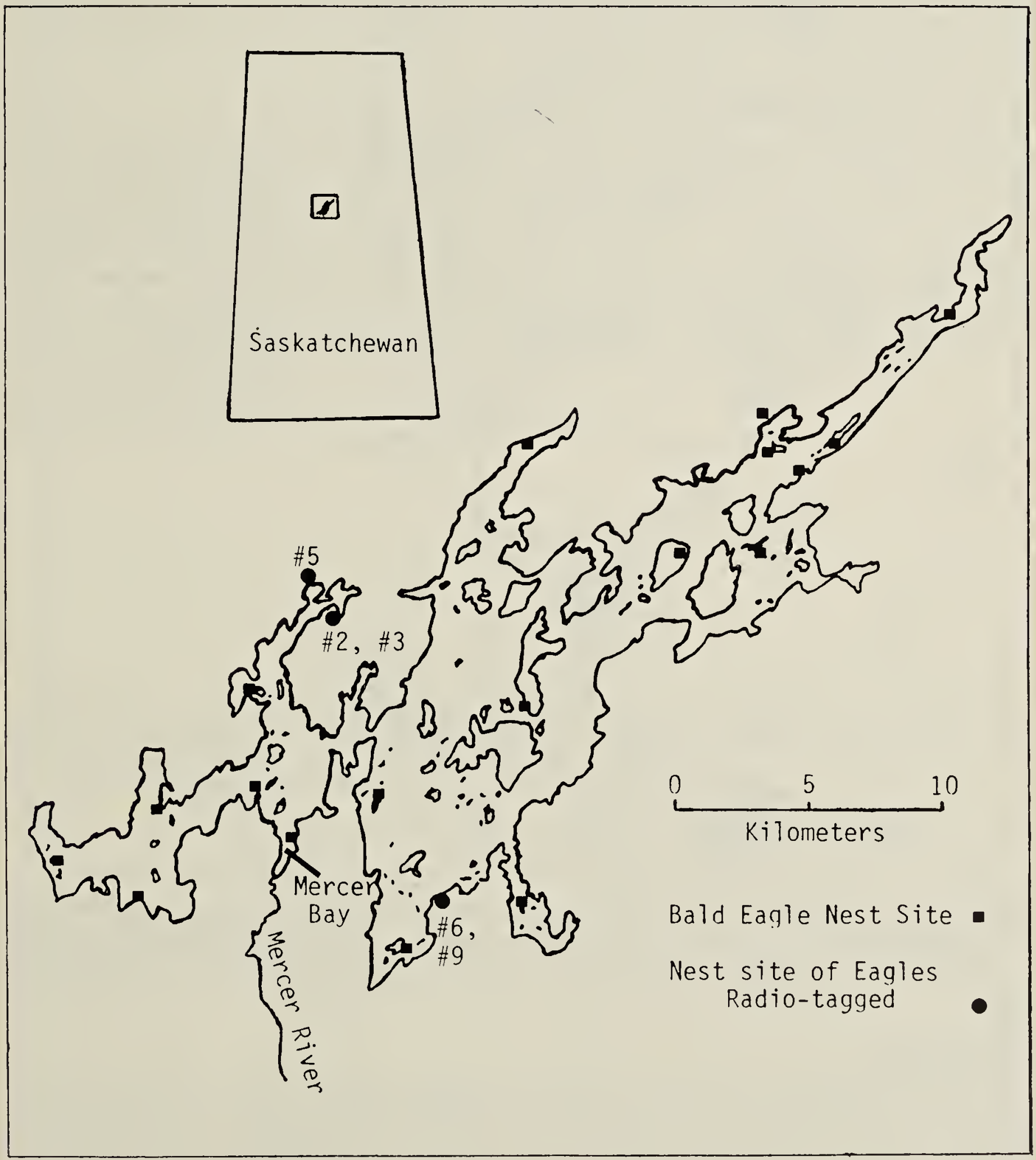

Figure 1. Bald Eagle nest sites and natal nests of juvenile Bald Eagles radio-tagged on Besnard Lake, Saskatchewan, July 1983. Numbers indicate receiver channel numbers. 


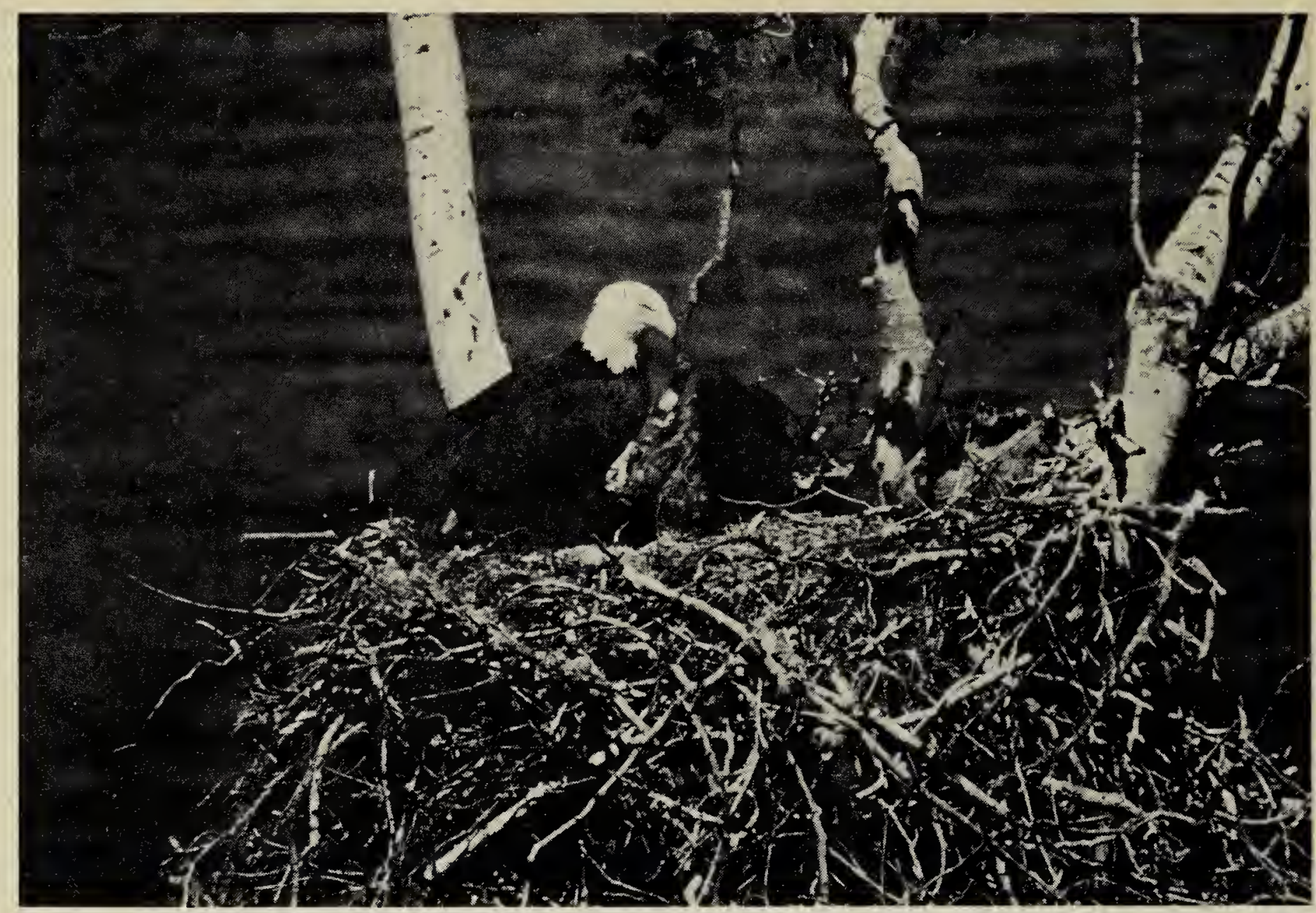

Adult Bald Eagle at nest

J. Gerrard

On 1 November 1983, Besnard Lake was surveyed by air to locate instrumented eagles. Only two $(\# 2, \# 6)$ were located, both at Mercer Bay (Fig. 1). Bad weather prevented inspection of Mercer Bay by boat until 3 November. Two adults and three immature/subadult eagles were seen but no radio-tagged eagles were located. Signals indicated one eagle, \#6, was in the vicinity of the Mercer River, about $2 \mathrm{~km}$ south of Mercer Bay (Fig. 1). Both radio-tagged eagles apparently left Besnard Lake on 2 November, the day after Mercer Bay froze over.

\section{Migration Routes}

From 4 November until cessation of tracking 15 November, eagles were monitored from fire towers (Fig. 2) and vehicles. Migration routes of radio-tagged eagles are shown in Fig. 2. Distance traveled in 6 days was $231 \mathrm{~km}$.

While moving through the boreal forest, eagle \#2 apparently oriented along heights of land, as shown by the proximity of his flight route to fire towers (Fig. 2). Once out of the boreal forest/Canadian shield country, he made an abrupt course change westsouthwest towards the Sturgeon River where he eventually roosted for the night. Leaving the Sturgeon River he again assumed a southerly direction. After crossing Highway 3, he travelled west-southwest, eventually stopping in the vicinity of the Thickwood Hills (Fig. 2).

Eagle \#2 was not observed in the company of any other eagles while in flight, however other eagles were seen along the route and were present at most stops and identified roosts.

\section{Flight Mechanics}

Migratory flights were easily distinguished from short flights within foraging areas (Fig. 2). Foraging flights were characterised by short, direct flights under $50 \mathrm{~m}$ in altitude, without soaring. Migratory flights 


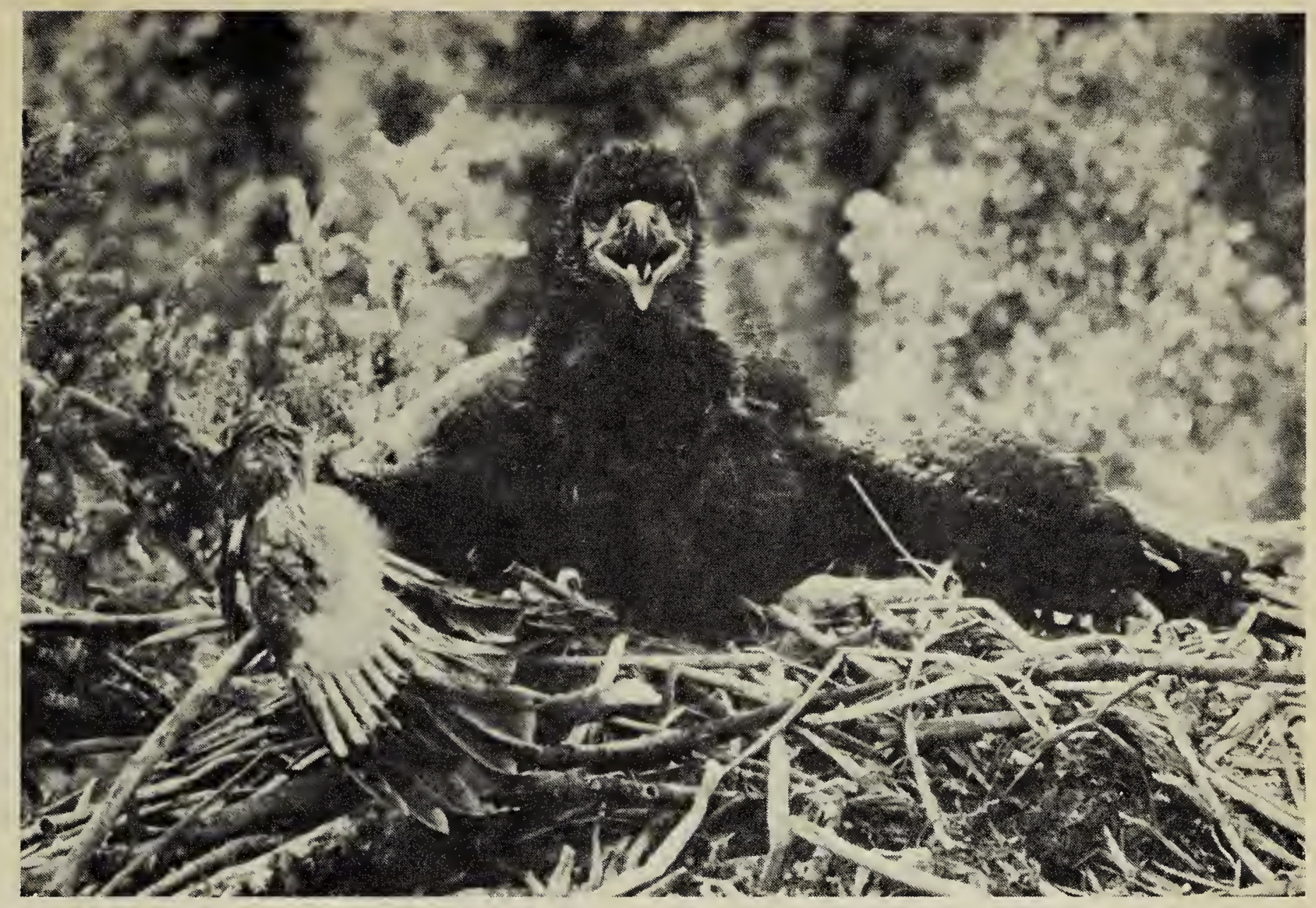

Eaglet in nest

J. Gerrard

were initiated by circling (soaring or powered flight) and followed by a glide or flapping flight in one compass direction, usually south or southwest.

Duration of migratory flights that were sufficiently documented to permit evaluation ranged from $30 \mathrm{sec}$. to $122 \mathrm{~min}$. [n(sample size $)=12, \bar{x}($ mean or average $)=44.2$ min., S.D.(standard deviation) $=38.2$ ] Distances covered per flight ranged from $200 \mathrm{~m}$ to $37.5 \mathrm{~km}(\mathrm{n}=4, \bar{x}=17 \mathrm{~km}$, S.D. = 14.7). Migratory flights were usually initiated between 1100 and $1300 \mathrm{~h}(\mathrm{n}=16$, mode $=1200 \mathrm{~h}$ ). Flights terminated between 1400 and $1550 \mathrm{~h}$. Average distance traveled was $32.8 \mathrm{~km} /$ day, and average speed in level (non-soaring) flight was $26 \mathrm{kmph}$ $(n=3)$.

Altitude of migratory flights ranged from $54 \mathrm{~m}$ to $180 \mathrm{~m}$ but averaged about $81 \mathrm{~m}$. Weather was overcast on all but 2 tracking days. On clear days eagle \#2 flew higher, generally 100-180 m.

\section{Wintering}

In January 1984 many wildlife refuges and other known Bald Eagle wintering areas in South Dakota, Nebraska, Oklahoma, Texas, Missouri and lowa were searched for radiotagged eagles. No signals were heard and no eagles wearing non-functioning backpack radios were seen.

\section{Homing}

In July 1984, Besnard Lake was surveyed by boat to search for returning radio-tagged eagles. No signals were heard and no eagles wearing non-functioning backpack radios were seen.

\section{Discussion}

Although data are incomplete, certain generalisations can serve as hypotheses to be tested in the future with adequate fund- 
ing and better equipment permitting larger samples, more fortuitous timing, and more complete tracking.

The condition of primary foraging areas on Besnard Lake appeared to be the major stimulus to initiate migration of juvenile eagles. Both radio-tagged eagles found on Besnard Lake in November were at Mercer Bay, even though they had fledged from nests over $8 \mathrm{~km}$ apart. Mercer Bay is known for its productive fishery and is closed to fishing. Both radio-tagged eagles were near the mouth of the Mercer River on 1 November when the river and the upstream stretches of the bay were free of ice. Between 1 and 3 November these areas froze over and the radio-tagged juveniles were subsequently not located on the lake. Other juvenile eagles were seen on the bay on 3 November but appeared in the company of adults. Possibly juvenile eagles without parental tutelage leave the natal areas earlier than their contemporaries. However, adults and immatures may have left the lake soon after 3 November.

Photoperiodic cues may be responsible for the initiation of spring migration for adult Bald Eagles. ${ }^{8} 7$ However, sensitivity to proximate ecological factors rather than photoperiodism would appear to be adaptive for the initiation of fall migration. Remaining in the natal/breeding area during years of mild weather, late ice-up, and abundant prey would minimise energy expenditures facilitating survival and productivity.

Orientation and navigation from Besnard Lake by eagle \#2 may have been facilitated primarily by physiography, after an initial compass direction was selected, since parental guidance was obviously lacking. However, migrating immatures may have been following courses of other eagles well out of visual range of human observers. Eagle \#2 apparently moved due south after leaving Besnard Lake orienting on heights of land as shown by the proximity of fire towers along the migration route (Fig. 2).
Once out of the boreal forest, the eagle made an abrupt turn to west-southwest eventually roosting in dense conifers along the Sturgeon River. This is the first large stand of conifers to be encountered south of the forest and the eagle may have cued on familiar ecotypes once in an unfamiliar area (parkland country). Subsequent movement was again south hinting at suncompass orientation but all but 2 days of migration were totally overcast. ${ }^{9}$ Gerrard and Hatch, and Harmata noticed that on days of total overcast on northward migration, eagles seldom flew, except locally. ${ }^{4} 7$ In the absence of celestial cues, eagle \#2 continued south until possibly within sight of other prominent physiographic features and/or familiar ecotypes in the Thickwood Hills (Fig. 2) $35-45 \mathrm{~km}$ away. Other eagles encountered enroute may have facilitated selection of roost sites and foraging areas and/or flight line.

Flight mechanics of radio-tagged juveniles on fall migration differed greatly from adult eagles tracked on spring mgration. ${ }^{7}$ Flight of juveniles was slower, altitudes lower, distances travelled smaller, and durations considerably shorter. This can be expected of a young eagle presumably not goaloriented and travelling over totally unfamiliar territory. However, an adult eagle followed for 5 days in 1982 also travelled relatively slowly and this pattern may be characteristic of fall migration. ${ }^{11}$

Stopover areas such as the area west of Leask (Fig. 2) may be essential for the survival of a large number of Bald Eagles over an extended period of time. Eagle \#2 remained in the Leask area for at least 4 days and fed there at least twice. The area appeared to contain an abundance and diversity of prey. Deer hunting season was in progress and eagles may have been foraging on viscera piles left by hunters. Sharptailed Grouse were observed daily and were used by eagles. Waterfowl frequented open water in the vicinity and probably were fed upon by eagles. Turnover of eagles may have been daily over weeks, supporting 
large numbers not evident at any one time. Many similar stopover areas in western North America may be threatened and every effort should be made to document their loction and importance to bald Eagles.

\section{Stopover Point}

From 10 November until last located 15 November, eagle \#2 remained in a $56 \mathrm{~km}^{2}$ area centered about $20 \mathrm{~km}$ west-southwest of Leask, $88 \mathrm{~km}$ north of Saskatoon. Five other Bald Eagles, two adults and three juveniles also frequented this area. Eagle \#2 was observed feeding here twice, once on a Sharp-tailed Grouse killed in a collision with a powerline and once on a Porcupine, apparently killed by an eagle. Martin and Padding lakes are also located in this area and waterfowl concentrated there. Although not seen chasing or feeding on waterfowl, the local eagles (including eagle \#2) commonly perched along the shoreline near waterfowl concentrations.

\section{Acknowledgements}

Funding for this study was provided by The American Wilderness Alliance and World Wildlife Fund-Canada. Robert L. Eng, William Gould, and John Monarch located radio-tagged eagles on Besnard Lake in August, 1983. C.J. and P.J. Harmata, Naomi, Charles, Pauline and Tom Gerrard assisted in transmitter attachment to eagles. Lynn Oliphant, and graduate students Paddy Thompson, Ian Warkentin and Betsy Haug, from University of Saskatchewan assisted in radio-tracking.

' GERRARD, J.M., P.N. GERRARD, W.J. MAHER and D.W.A. WHITFIELD 1975 Factors incluencing nest site selection of Bald Eagles in northern Saskatchewan and Manitoba. Blue Jay 33:131-139.

${ }^{2}$ GERRARD, J.M., P.N. GERRARD and D.W.A. WHITFIELD 1980 Behavior of a non-breeding Bald Eagle. Can. Field Nat. 94:391-397.
${ }^{3}$ GERRARD, J.M. and A.R. HARMATA 1982 The movements of a pair of adult Bald Eagles on their breeding grounds. Proc. of 1982 annual fall meeting of the Raptor Res. Found. (Abstracts only).

${ }^{4}$ GERRARD, J.M. and D.R.M. HATCH 1983 Bald Eagle migration through southern Saskatchewan and Manitoba and North Dakota. Blue Jay 41:146-154.

${ }^{5}$ GERRARD, J.M., D.W.A. WHITFIELD, P. GERRARD, P.N. GERRARD and W.J. MAHER 1978 Migratory movements and plumage of subadult Saskatchewan Bald Eagles. Can. Field Nat. 92:375-382.

${ }^{6}$ GERRARD, P., J.M. GERRARD, D.W.A. WHITFIELD and W.J. MAHER 1974 Post-fledging movements of juvenile Bald Eagles. Blue Jay 32:218-226.

7 HARMATA, A.R. 1984 Bald Eagles of the San Luis Valley, Colorado: their winter ecology and spring migration. Ph. D. Diss. Montana St. Univ., Bozeman. 222 pp.

${ }^{8}$ KING, J.R. and D.S. FARNER 1963 The relationship of fat deposition to Zugenruhe. Condor 65:200-223.

${ }^{9}$ KRAMER, G. 1957 Experiments on bird orientation and their interpretation. Ibis 94:265-285.

10 LEIGHTON, F.A., J.M. GERRARD, P. GERRARD, D.W.A. WHITFIELD and W.J. MAHER 1979 An aerial census of Bald Eagles in Saskatchewan. J. Wildl. Manage. 43:61-69.

${ }^{11}$ NIJSSEN, A.L., A.R. HARMATA and J.M. GERRARD 1985. The initial southward migration of an adult female Bald Eagle. In: The Bald Eagle in Canada. (J.M. Gerrard and T.N. Ingram, eds.), White Horse Plains Publishers, Headingley, Manitoba, pp 186-190.

12 WHITFIELD, D.W.A., J.M. GERRARD, W.J. MAHER and D.W. DAVIS 1974 Bald Eagle nesting habitat, density and reproduction in central Saskatchewan and Manitoba. Can. Field Nat. 88:399-407. 